\title{
Bad and Bid - potential background players in preneoplastic to neoplastic shift in human endometrium
}

\author{
D. DRIAK ${ }^{1, *}$, M. DVORSKA ${ }^{1}$, P. BOLEHOVSKA ${ }^{1}$, I. SVANDOVA ${ }^{2,3}$, J. NOVOTNY $^{2}$, M. HALASKA ${ }^{1}$
}

${ }^{1}$ Department of Gynaecology and Obstetrics, Charles University in Prague, First Faculty of Medicine and Hospital Bulovka, Prague, Czech Republic; ${ }^{2}$ Department of Physiology, Faculty of Science, Charles University in Prague, Prague, Czech Republic; ${ }^{3}$ Department of Biochemistry of Membrane Receptors, Institute of Physiology, Academy of Sciences of the Czech Republic, Prague, Czech Republic

*Correspondence:driak@seznam.cz

Received October 15, 2013 / Accepted December 2, 2013

\begin{abstract}
The most common malignancies of the female genital tract are endometrial carcinomas, whose are generally proceeded by hyperplasia. The maintenance of tissue homeostasis is to great extent governed by apoptosis, whose defects can lead to the preneoplastic and/or cancerous changes. Endometrial apoptosis involves among others three groups of proteins of the Bcl-2 family. First group contains anti-apoptotic proteins (e. g. Bcl-2, Bcl-xL). The other two groups belong to the pro-apoptotic proteins with three (e. g. Bax, Bak) or one (e. g. Bad, Bid) so-called BH domains. Bad and Bid trigger the oligomerization of Bak and Bax protein, which permeabilize the outer mitochondrial wall. Unlike Bid, Bad cannot directly trigger apoptosis. Instead, Bad lowers the threshold at which apoptosis is induced, by binding anti-apoptotic Bcl-2 proteins. However, their mutual counterbalance or synergism in the human endometrium has not been reported yet.

In this study, the levels of Bid and Bad were measured using SDS-PAGE and Western blotting with specific antibodies, with the aim to analyse expression of Bid and Bad proteins in normal (NE), hyperplastic (HE) and cancerous (CE) endometrium.

We demonstrated that Bid expression in CE reached only $47 \%$ and $50 \%$ of this observed in NE and HE. Conversely, Bad expression in $\mathrm{HE}$ reached only $40 \%$ and $36 \%$ of this observed in NE and CE, respectively. We detected no significant changes of Bid expression between HE and NE, and levels of Bad protein were not different between CE and NE.

Trend of Bid and Bad protein expression is clearly opposite in HE and CE. We hypothesise that disrupted apoptotic program in CE seems to be reduced further by lowering levels of direct apoptotic trigger protein Bid. We suggest that the adenocarcinoma tissue of human endometrium thus tries to strengthen its apoptotic effort by lowering the apoptotic threshold via higher Bad levels.
\end{abstract}

Key words: Bad, Bid, cancerogenesis, human endometrium

Apoptosis is a complex, ordered and highly orchestrated process that involves intrinsic or extrinsic pathways and plays a crucial role in normal development and removal of malignant, damaged or infected cells. It is controlled by many regulating factors such as death receptors on the cell membrane, B-cell lymphoma-2 (Bcl-2) family of proteins, expression of caspases and/or inhibitors of apoptosis proteins (IAPs), mutation of tumor suppressor protein p53 [1]. Disruptions can occur at any stage of the apoptotic cascade. Disruption of the physiological apoptotic process is known to contribute to many pathological conditions such as developmental defects, neurodegenerative disorders, persistent infections, autoimmune responses and initiation of cancerogenesis $[1,2]$.
Human endometrium is one of the few tissues undergoing a cyclic process of apoptosis, proliferation and differentiation. This process is strongly influenced by endocrine state of organism and depends especially on $17 \beta$-estradiol and progesterone levels [3]. Apoptosis is reported to be detected in late secretory and menstruating endometrium and scare in normal proliferating endometrium or at the beginning of the secretory phase $[4,5]$.

It was demonstrated that endometrial apoptosis among others involves proteins of the Bcl-2 family $[6,7]$. Bcl-2 family of proteins comprises more than 25 structurally similar proteins. All proteins of the $\mathrm{Bcl}-2$ protein family share at least one $\mathrm{Bcl}-2$ homology $(\mathrm{BH})$ region. According to the function 
and presence $\mathrm{BH}$ domain/s, the Bcl-2 family members are divided into three groups. First group contains anti-apoptotic proteins with four (BH1-BH4) domains (e. g. Bcl-2, Bcl-xL, $\mathrm{Bcl}-\mathrm{w}, \mathrm{Mcl}-1, \mathrm{Bcl}-\mathrm{B}, \mathrm{Bfl}-1)$. To the second group belong proapoptotic proteins with three $\mathrm{BH}$ domains BH1-3 (e. g. Bax, Bak, Bok). Members of the third group are also pro-apoptotic. They possesses only one $\mathrm{BH} 3$ domain and therefore they are called BH3-only proteins (e. g. Bad, Bid, Bim, Bik, Bmf, Hrk, Puma, Noxa) [1].

Hallmark of the intrinsic apoptotic pathway is cytochrome $c$ release permitted by the oligomerizations of pro-apoptotic Bak and Bax, which create pores and permeabilize the outer mitochondrial membrane in a process known as mitochondrial outer membrane permeabilization (MOMP). There are two models of Bax and Bak activation: indirect and direct. According to indirect model, Bak and Bax are activated without direct interactions with activator $\mathrm{BH} 3$-only proteins. In direct model, activation of Bax and Bak requires direct interaction between these proteins and activator $\mathrm{BH} 3$-only proteins (e.g. $\mathrm{Bid})$. Interaction leads to conformational changes and subsequent activation of Bax and Bak. This interaction of Bak and Bax is also provided by sensitizer BH3-only proteins (e.g. Bad), which inhibit anti-apoptotic activity of Bcl-2 and Bcl-xL [8].

$\mathrm{Bad}$ and Bid can cause a healthy cell to become inappropriately apoptotic $[9,10,11,12]$. Key step for Bid activation is cleavage of $\mathrm{N}$-teminal region. Truncated Bid (tBid) is about 350 times more potent than full-length Bid [13]. tBid interacts with Bax, in turn leading to the insertion of Bax into organelle membranes, primarily the outer mitochondrial membrane. Bax is believed to interact with, and induce the opening of the mitochondrial voltage-dependent anion channel. Alternatively, growing evidence suggest that activated Bax and/or Bak form an oligomeric pore in the outer membrane. Sinicrope et al. by means of TUNEL methods found that Bid expression was significantly correlated with increased tumor cells apoptosis [14]. Bad is regulated by its phosphorylation - inactivation of AKT induces dephosphorylation of Bad and its activation. Dephosphorylated Bad forms a heterodimmer with Bcl-2 and/or Bcl-xL, inactivating them and thus allowing Bax/Baktriggered apoptosis. Dimerization of Bad with Bcl-2 results in displacement of Bax from Bcl-2/Bax complex, thereby causing restoration of Bax-mediated apoptosis [15].

Table 1. Clinical characteristics of healthy women (NE), women with hyperplasia (HE) and women with endometrial carcinoma (CE).

\begin{tabular}{lccc}
\hline & $\mathrm{NE}(\mathrm{n}=10)$ & $\mathrm{HE}(\mathrm{n}=8)$ & $\mathrm{CE}(\mathrm{n}=8)$ \\
\hline Age & $42,75 \pm 1,93$ & $53 \pm 3,90$ & $67 \pm 1,94$ \\
Testosterone $(\mathrm{nmol} / \mathrm{l})$ & $0,98 \pm 0,11$ & $3,1 \pm 1,81$ & $1,35 \pm 0,43$ \\
Progesterone $(\mathrm{nmol} / \mathrm{l})$ & $1,41 \pm 0,42$ & $1,17 \pm 0,44$ & $0,93 \pm 0,09$ \\
$17 \beta$-estradiol $(\mathrm{nmol} / \mathrm{l})$ & $0,21 \pm 0,06$ & $0,19 \pm 0,03$ & $0,23 \pm 0,05$ \\
Prolactin $(\mu \mathrm{g} / \mathrm{l})$ & $16,34 \pm 4,13$ & $11,72 \pm 2,11$ & $60,78 \pm 14,15$ \\
FSH (IU/l) & $32,18 \pm 9,95$ & $28,6 \pm 8,04$ & $32,7 \pm 5,62$ \\
LH (IU/l) & $18,66 \pm 6,46$ & $21,65 \pm 7,11$ & $26,65 \pm 9,28$ \\
\hline
\end{tabular}

Abbreviations: follicle-stimulating hormone (FSH), luteinizing hormone (LH)
$\mathrm{Bcl}-2 / \mathrm{Bax}$ ratio is a very important factor for predicting cell fate. Whereas high $\mathrm{Bcl}-2 / \mathrm{Bax}$ ratio $(>1)$ makes cells resistant to apoptotic stimuli, low $\mathrm{Bcl}-2 / \mathrm{Bax}$ ratio $(<1)$ predisposes cells to apoptosis. We described previously Bcl-2/Bax ratio higher than 1 in endometrial carcinoma, whereas hyperplastic endometrium Bcl-2/Bax ratio we found lesser than 1, thus indicating tendency of hyperplastic endometrium to eliminate its modified cells by the process of apoptosis much more effectively than in the cancerous tissue [16]. The delicate balance of Bcl-2/Bax complexes can be destroyed by dimerization of Bad with Bcl-2, rebalancing also cell homeostasis in turn. To investigate the potential involvement Bid and Bad protein in tuning of different apoptotic approaches of hyperplastic and cancerous endometrial tissue, we tried to compare levels of Bid and Bad protein in the present study.

\section{Patients and methods}

Endometrial samples were obtained from 26 informed patients (mean age of 58 years) who underwent probatory curettage, hysteroresection or hysterectomy. The tissue specimens were classified as follows: normal endometrium obtained in proliferative phase of the menstrual cycle $(\mathrm{NE} ; \mathrm{n}=10)$, endometrium from patients with endometrial hyperplasia $(\mathrm{HE} ; \mathrm{n}=8)$ and endometrium from patients with endometrial carcinoma (CE; grades I and/or II, $\mathrm{n}=8$ ). After being removed, tissue was frozen immediately on dry ice. Histopathological investigation was carried out using routine histopathologic methods. Samples of venous blood for assessment of hormonal levels were collected from the same patients before operation. Clinical characterictics of the groups are shown in Table 1. Written consent was obtained from all subjects of the study.

Preparation of samples. Following surgery, the obtained tissue was washed in cold normal saline to eliminate any contaminating blood. Endometrial stroma was removed by microdissection under optic control. Resulting material was then pooled for each experimental group. When not used immediately, the tissue was frozen in liquid nitrogen and stored until use at $-80^{\circ} \mathrm{C}$.

To isolate cytosol fraction, tissue was brought to $0^{\circ} \mathrm{C}$, cut into small pieces in homogenization buffer $(20,0 \mathrm{mM}$ Tris- $\mathrm{HCl}$; 2,5 mM EDTA; 50,0 mM NaF; 10,0 mM Na $\mathrm{P}_{2} \mathrm{O}_{7}, 1 \%$ Triton $\mathrm{X}-100 ; \mathrm{pH} 7.4$; all the chemicals from Sigma, USA) containing complete protease inhibitor cocktail for mammalian tissues (AEBSF, aprotinin, leupeptin, bestatin, pepstatin A, E-64; Sigma, USA) and homogenized in ten volumes of the buffer on ice by using tight teflon-glass homogenizer ( $3 \times 10 \mathrm{~min}$ at 2000 rpm; Brown, Germany). The homogenate was centrifuged at low-speed at $10000 \mathrm{~g}$ for $2 \times 10 \mathrm{~min}$ at $4^{\circ} \mathrm{C}$. Arising supernatant and the pellet were subsequently separated. Supernatant was then collected and snap frozen in liquid nitrogen and stored at $-80^{\circ} \mathrm{C}$ until use. The concentration of the proteins was determined by the method of Lowry.

Immunoblotting. The sample containing $25 \mu \mathrm{g}$ of protein was solubilized in Laemmli buffer $(50 \mathrm{mM}$ Tris/HCl, $\mathrm{pH} 8,0$, 
A

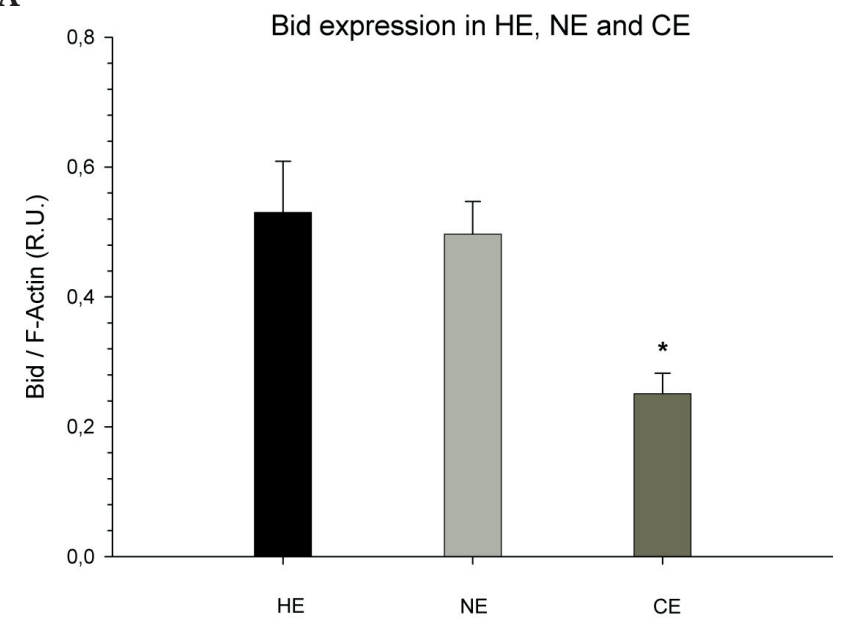

$43 \mathrm{kDa} \rightarrow$

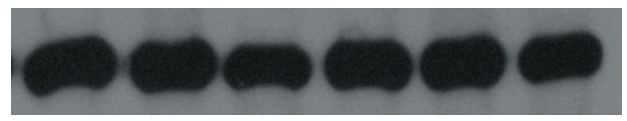

$23 \mathrm{kDa} \rightarrow$

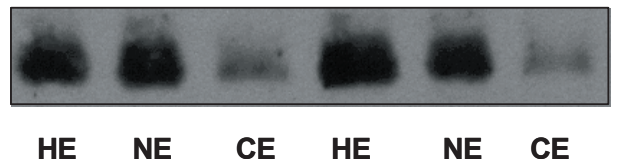

B
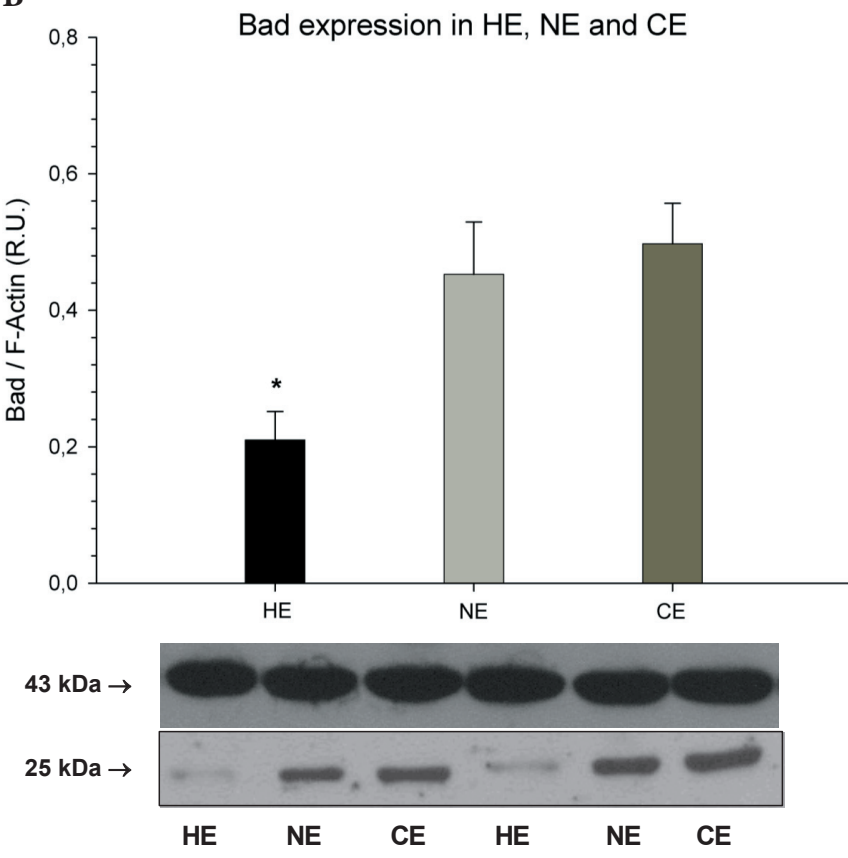

Figure 1. Representative Western blot analysis of Bid (A) and Bad (B) levels in two samples each of hyperplastic (HE), cancerous (CE) and normal (NE) endometrium. $25 \mu \mathrm{g}$ of protein was loaded to each lane. Bid band was detected at $23 \mathrm{kDa}$, Bad at $25 \mathrm{kDa}$, F-Actin at $43 \mathrm{kDa}$. Protein intensities were normalized to intensities observed for F-Actin as internal control. Results are in relative units and represent mean of seven dependent experiments \pm S.E.M. $\left({ }^{*}, \mathrm{p}<\mathbf{0 . 0 5}\right)$.

$6 \%(\mathrm{w} / \mathrm{v})$ dithiothreitol, $5 \%(\mathrm{w} / \mathrm{v})$ SDS, $0,005 \%(\mathrm{w} / \mathrm{v})$ Bromphenol Blue). The proteins were resolved by standard SDS-PAGE (15\% gels). The electrophoresis was run at $200 \mathrm{~V}$ for $1 \mathrm{~h}$, using a Mini Protean II gel kit (Bio-Rad). After the SDS-PAGE, proteins were transferred to nitrocellulose membrane using wet apparatus. Blotting was run at $35-50 \mathrm{~mA}$ overnight. The membrane was blocked for $1 \mathrm{~h}$ in $5 \%$ fat-free milk in PBS$\mathrm{T}$ buffer (PBS containing 0,05\% (v/v) Tween 20). Then the membrane was incubated for $2 \mathrm{~h}$ at room temperature in appropriate primary antibody in $1 \%$ fat-free milk in PBS-T buffer. The following primary antibodies were used: against Bid 5C9 (sc-56025, Santa Cruz Inc. 1:500), against Bad K14 (sc-6541, Santa Cruz Inc, 1:500), against F-Actin (C-11, Santa-Cruz Inc, 1:1000). After the primary antibody was removed, the blot was washed 3 times $10 \mathrm{~min}$ in PBS-T buffer. Subsequently, the membrane was incubated for $1 \mathrm{~h}$ at room temperature in appropriate secondary antibody (Santa Cruz Inc., 1:15 000-20 $000)$ in $1 \%$ fat-free milk PBS-T buffer. After the removing of secondary antibody the membrane was extensively washed 3 times 10 min in PBS-T buffer and the blot was visualized by ECL (Amersham).

Statistical analysis. The levels of Bid, Bad and Actin were analyzed and quantified by scanning densitometry (ImageQuant TL v 2005, Amersham Biosciences). Protein expression was normalized to band intensities observed for F-Actin used as internal control. Thus, values of protein levels are given in relative units (R.U.) determined as ratio of mean protein band optical density to mean F-Actin band optical density on the same membrane. In other words, blots were scanned for quantification of band intensity. The expression level corresponds to the number of black pixels scanned of each band. The results were expressed as Optical Density (OD) in arbitrary units. FActin was used as a loading control. The amount of protein was analysed as a ratio between the OD of target protein and OD of F-Actin, which is expressed as relative units (R.U.). Statistical analysis was performed using the SigmaStat 3.5 program (Systat Software, Inc.). One-way ANOVA test was used. P-values less than 0.05 were considered statistically significant.

\section{Results}

To establish Bid and Bad protein levels, immunoblotting experiments were performed in normal, hyperplastic and cancerous human endometrium. Bid and Bad proteins were detected in all tissue samples. F-Actin, loaded as an internal control, was detected at $43 \mathrm{kDa}$ (Figure $1 \mathrm{~A}, \mathrm{~B}$ ). Interestingly, experiments demonstrated opposite tendencies of Bid and Bad protein levels in hyperplastic and cancerous endometrium, 
Table 2. Level of Bid and Bad protein in hyperplastic (HE), cancerous (CE) and normal (NE) endometrium. Results are in relative units and represent mean of seven independent experiments \pm S.E.M. $(p<0.05)$.

\begin{tabular}{lccc}
\hline & HE $(n=8)$ & NE $(n=10)$ & CE $(n=8)$ \\
\hline Bid (R.U.) & $0.53 \pm 0.08$ & $0.50 \pm 0.05$ & $0.25 \pm 0.03$ \\
Bad (R.U.) & $0.18 \pm 0,02$ & $0.45 \pm 0.08$ & $0.50 \pm 0.06$ \\
\hline
\end{tabular}

when compared to normal endometrium. Bid protein level was more than $50 \%$ lower in cancerous endometrium as compared to hyperplastic endometrium $(0.25$ and 0.53 R.U. respectively, $\mathrm{P}=0.005$, Figure 1 , Table 2 ). We found no significant difference of Bid level between hyperplastic and normal endometrium.

In contrast, Bad protein level in hyperplastic endometrium was only $40 \%$ of Bad protein level in normal endometrium $(\mathrm{P}=0.019)$. Interestingly, immunoblotting with the Bad antibody revealed the highest level of Bad protein in cancerous endometrium (0.5 R.U.). Level of Bad protein in normal endometrium was slightly lower than in the cancerous samples, but there was no significant difference (Figure 1, Table 2).

\section{Discussion}

The maintenance of tissue homeostasis and precisely balanced counteracting of cellular proliferation and cell death is essential for tissue integrity. Bcl-2 protein family is a part of complex regulatory network of apoptosis and includes both the anti-apoptotic and pro-apoptotic molecules. Their interplay can mirror in so-called apoptotic rheostat - a cellular ratio of $\mathrm{Bcl}-2 / \mathrm{Bax}$ proteins, pointing to cell pro-surviving or pro-apoptotic tendencies $[17,18]$. In our previous study, we described $\mathrm{Bcl}-2 / \mathrm{Bax}$ ratio higher than 1 in endometrial carcinoma, whereas hyperplastic endometrium Bcl-2/Bax ratio was established lesser than 1. A relatively high cancerous Bcl$2 /$ Bax ratio observed in our previous experiments can indicate a deregulation of endometrial tissue apoptotic program, which should eliminate malignant cells. Thus, the onset and progress of endometrial malignancy could be linked to increased proliferation of the cells with defects in control of final execution stages of apoptosis [16]. In the current study we focus on Bid and Bad proteins, the two important background players in adjustment of the apoptosis show.

Pro-apoptotic Bid protein mediates both extrinsic and intrinsic apoptotic pathways. Bad is also known to promote apoptosis through the intrinsic mitochondrial pathway. Bid and Bad are both post-transcriptionally regulated and engage anti-apoptotic proteins to constrain them. However, unlike Bid, Bad cannot directly trigger apoptosis $[19,20]$. It sensitizes the cell for apoptotic signals by forming selective dimmers with anti-apoptotic proteins Bcl-2 and Bcl-xL [21]. In this report, we show for the first time the opposite nature of Bid and Bad regulatory protein levels in preneoplastic and hyperplastic endometrium.
The lowest expression of Bid protein we observed in adenocarcinoma cells with Bcl-2/Bax ratio higher than 1, e.g. in the tissue set in pro-survival manner. Contrariwise, hyperplastic and normal endometrium exhibited two times higher and almost similar level of Bid expression, when compared to the cancerous tissue. Downregulation of Bid expression could be one of the features of neoplastic transformation. Similarly to Sinicrope et al., we observed higher Bid expression and lower Bad expression in more pro-apoptotic-mood hyperplastic tissue, in which the apoptotic rheostat value was lower than in both normal and especially cancerous endometrium. These authors found that Bid, but not Bad, expression was significantly correlated with a higher values cell apoptosis in colorectal tumors. They conclude that Bid is highly potent inducer of apoptosis compared with the selective BH3 protein Bad [14]. Other groups also studied the importance of Bad and Bid proteins in tumorigenesis and in apoptotic susceptibility. A spontaneous development of a clonal malignancy that resembles human chronic myelomonocytic leukemia was described in mice lacking Bid [22]. Ranger et al. reported on spontaneous tumorigenesis in a cohort of aged Bad-/- mice, with diffuse large B-cell lymphomas as the most frequent tumor observed [23]. Taghiyev et al. demonstrated that overexpression of Bad allows prostatic carcinoma cell line LNCaP to overcome a block at the mitochondrial level and undergo apoptosis [24]. Howells et al., in their theoretical paper, present the incorporation of Bad and its various modifications in a model of the tBid-induction of Bak or the tBid-induction of Bax. They show the total concentration level of tBid, guaranteed to trigger apoptosis, as a bilinear function of the total Bad. In particular, their formulas explain how the pro-apoptotic protein Bad lowers the threshold at which tBid induces Bak/ Bax activation. They conclude that Bad reduces the level of total $\mathrm{Bcl}-2 / \mathrm{Bcl}-\mathrm{xL}$ available to inhibit tBid signalling in the mitochondria, thus lowering the threshold at which tBid activates Bak/Bax oligomerization [25]. Stated another way, Bad can have a profound effect on whether a cell becomes apoptotic or not.

The tissue homeostatic effort is to eliminate preneoplastic and neoplastic cells. Taken together, we hypothesize here that the apoptotic program of hyperplastic endometrial tissue is not impaired to such an extend as in the case of the cancerous endometrium, which reflects also in pro-apoptotic Bcl-2/Bax ratio and relatively high Bid expression in the hyperplastic endometrium. The adenocarcinoma tissue of endometrium works in more proliferative than apoptotic manner (pro-survival $\mathrm{Bcl}-2 / \mathrm{Bax}$ ratio, relatively low Bid expression), thus trying to strengthen its eliminative apoptotic effort by lowering the apoptotic threshold via higher Bad levels.

Acknowledgements: This work was supported by The Ministry of Education, Youth, and Sports of the Czech Republic grant No. MSM0021620858, and by the grant No. GACR P207/12/0919 of the Czech Science Foundation. 


\section{References}

[1] WONG RSY Apoptosis in cancer: from pathogenesis to treatment. J Exp Clin Cancer Res 2011; 30: 87. http://dx.doi. org/10.1186/1756-9966-30-87

[2] PETROS AM, OLEJNICZAK ET, FESIK SW Structural biology of the Bcl-2 family of proteins. Biochimica et Biophysica Acta 2004; 1644: 83-94. http://dx.doi.org/10.1016/ j.bbamcr.2003.08.012

[3] SHIOZAWA T, LI SF, NAKAYAMA K, NIKAIDO T, FUJII S Relationship between the expression of cyclins/cyclin-dependent kinases and sex-steroid receptors/Ki67 in normal human endometrial glands and stroma during the menstrual cycle. Mol Hum Reprod 1996; 2: 745-752. http://dx.doi.org/10.1093/ $\underline{\text { molehr/2.10.745 }}$

[4] TAO XJ, TILLY KI, MARAVEI DV, SHIFREN JL, KRAJEWSKI S. et al. Differential expression of members of the bcl-2 gene family in proliferative and secretory human endometrium: glandular epithelial cell apoptosis is associated with increased expression of bax. J Clin Endocrinol Metab 1997; 82: 2738-2746.

[5] VASKIVUO T, STENBAECK F, TAPANAINEN J Apoptosis and apoptosis-related factors bci-2, bax, tumor necrosis factor-, and NF- $\mu \mathrm{B}$ in human endometrial hyperplasia and carcinoma. Cancer 2002; 95: 1463-1471. http://dx.doi.org/ $10.1002 /$ cncr.10876

[6] ABE H, SHIBATA MA, OTSUKI Y Caspase cascade of Fasmediated apoptosis in human normal endometrium and endometrial carcinoma cells. Mol Hum Reprod 2006; 12:, 535-541. http://dx.doi.org/10.1093/molehr/gah260

[7] WATANABE H, KANZAKI H, NARUKAWA S, INOUE T, KATSURAGAWA H. et al. Bcl-2 and Fas expression in eutopic and ectopic human endometrium during the menstrual cycle in relation to endometrial cell apoptosis. Am J Obstet Gynecol 1997; 176: 360-368. http://dx.doi.org/10.1016/S00029378(97)70499-X

[8] DANIAL N BCL-2 family proteins: critical checkpoints of apoptotic cell death. Clin Cancer Res 2007; 13: 7254-7263. http://dx.doi.org/10.1158/1078-0432.CCR-07-1598

[9] BERTHIER A, LEMAIRE-EWING S, PRUNET C, MONIER $S$, ATHIAS A. et al. Involvement of a calcium-dependent dephosphorylation of Bad associated with the localization of Trpc-1 within lipid rafts in 7-ketocholesterol-induced THP-1 cell apoptosis. Cell Death Differ 2004; 11: 897-905. http://dx.doi.org/10.1038/sj.cdd.4401434

[10] LAW PTW, WONG CH, AU TCC, CHUCK CP, KONG SK. et al. The 3 a protein of severe acute respiratory syndrome-associated coronavirus induces apoptosis in Vero E6 cells. J General Virol 2005; 86: 1921-1930. http://dx.doi.org/10.1099/vir.0.80813-0

[11] SAITO A, HAYASHI T, OKUNO S, FERRAND-DRAKE M, CHAN PH Overexpression of copper/zinc superoxide dismutase in transgenic mice protects against neuronal cell death after transient focal ischemia by blocking activation of the Bad cell death signaling pathway. J Neurosci 2003; 23: 1710-1718.

[12] YIX, YIN XM, DONG Z Inhibition of Bid-induced apoptosis by Bcl-2. J Biol Chem 2003; 278: 16992-16999. http://dx.doi. org/10.1074/jbc.M300039200
[13] ZHA J., WEILER S, OH K, WEI M, KORSMEYER S Posttranslational N-myristoylation of BID as a molecular switch for targeting mitochondria and apoptosis. Science 2000; 290: 1761-1765. http://dx.doi.org/10.1126/science.290.5497.1761

[14] SINICROPE FA, REGO RL, FOSTER NR, THIBODEAU SN, ALBERTS SA. et al. Proapoptotic Bad and Bid protein expression predict survival in stages II and III colon cancers. Clin Cancer Res 2008; 14: 4128-4133. http://dx.doi. org/10.1158/1078-0432.CCR-07-5160

[15] ZHA J, HARADA H, YANG E, JOCKELJ, KORSMEYER S Serine phosphorylation of death agonist $\mathrm{BAD}$ in response to survival factor results in binding to 14-3-3 not BCL-X (L). Cell 1996; 87: 619-628. http://dx.doi.org/10.1016/S0092-8674(00)81382-3

[16] DRIAK D, DVORSKA M, SVANDOVA I, SEHNAL B, BENKOVA K. et al. Changes in expression of some apoptotic markers in different types of human endometrium. Fol Biol 2011; 57: 104-111.

[17] JIN Z, EL-DEIRY WS Overview of cell death signaling pathways. Cancer Biol Ther 2005; 4: 139-163. http://dx.doi. org/10.4161/cbt.4.2.1508

[18] REED J Proapoptotic multidomain Bcl-2/Bax-family proteins: mechanisms, physiological roles, and therapeutic opportunities. Cell Death Differ 2006; 13: 1378-1386. http://dx.doi. org/10.1038/sj.cdd.4401975

[19] GOLDSMITH KC, LIU X, DAM V, MORGAN BT, SHABBOUT $M$. et al. BH3 peptidomimetics potently activate apoptosis and demonstrate single agent efficacy in neuroblastoma. Oncogene 2006; 25: 4525-4533. http://dx.doi. org/10.1038/sj.onc. 1209489

[20] KUWANA T, BOUCHIER-HAYES L, CHIPUK JE, BONZON $\mathrm{C}$, SULLIVAN BA. et al. $\mathrm{BH} 3$ domains of $\mathrm{BH} 3$-only proteins differentially regulate Bax-mediated mitochondrial membrane permeabilization both directly and indirectly. Mol Cell 2005; 17: 525-535. http://dx.doi.org/10.1016/j.molcel.2005.02.003

[21] PUTHALAKATH H, STRASSER A Keeping killers on a tight leash: transcriptional and post-translational control of the pro-apoptotic activity of BH3-only proteins. Cell Death Differ 2002; 9: 505-512. http://dx.doi.org/10.1038/sj.cdd.4400998

[22] ZINKEL SS, ONG CC, FERGUSON DO, IWASAKI H, AKASHI K. et al. Proapoptotic BID is required for myeloid homeostasis and tumor suppression. Genes Dev 2003; 17: 229-239. http://dx.doi.org/10.1101/gad.1045603

[23] RANGER AM, ZHA J, HARADA H, DATTA SR, DANIAL NN. et al. Bad-deficient mice develop diffuse large B cell lymphoma. Proc Natl Acad Sci USA 2003; 100: 9324-9329. http://dx.doi.org/10.1073/pnas.1533446100

[24] TAGHIYEV AF, GUSEVA NV, HARADA H, KNUDSON CM, ROKHLIN OW. et al. Overexpression of BAD potentiates sensitivity to tumor necrosis factor-related apoptosis-inducing ligand treatment in the prostatic carcinoma cell line LNCaP. Mol Cancer Res 2003; 1: 500-507.

[25] HOWELLS CC, BAUMANN WT, SAMUWELS DC, FINKELSTEIN CV The Bcl-2-associated death promoter (BAD) lowers the threshold at which the Bcl-2-interacting domain death agonist (BID) triggers mitochondria disintegration. J Theor Biol 2011; 271: 114-123. http://dx.doi.org/10.1016/ j.jtbi.2010.11.040 